\title{
Perilaku Produsen pada Model Kemitraan Go Food dalam Prespektif Ekonomi Islam (Studi Kasus Daerah Wirobrajan, Yogyakarta)
}

\author{
Meita Masfufah, Sitti Achiria \\ Pascasarjana Fakultas Ilmu Agama Islam (FIAI) Universitas Islam Indonesia (UII) \\ Daerah Istimewa Yogyakarta \\ Email:meita_masfufah@yahoo.com, sitti.achiria@uii.ac.id
}

\begin{abstract}
Producer behavior is a company that helps increase the value of goods or services that produce consumption needs, partnership is cooperation between two parties with equal and mutually beneficial needs. The study aims to review how the partnership model between food producers and parties go food gojek, the research method used is qualitative descriptive by collecting and interviewing Go Food partners in the Wirobrajan area of Yogyakarta, producers feel greatly helped by becoming partners Go food Which experience Riding in sales, can help market their stalls online. Read more about distributing faster and free to customers themselves to buy products from suppliers without having to come to the shop.
\end{abstract}

Keyword: producer behavior, patnership, Go Food

\begin{abstract}
Abstrak
Perilaku Produsen adalah suatu lembaga perusahaan perorangan yang berperan dalam menaikan nilai guna suatu barang atau jasa sehingga menghasilkan barang konsumsi untuk memenuhi kebutuhan, kemitraan adalah kerja sama antara dua pihak dengan kewajiban yang setara dan saling menguntungkan. Penelitian ini bertujuan untuk mengetahui bagaimana model kemitraan antara pengusaha produsen makan dengan pihak Go Food Gojek, metode penelitian yang digunakan kualitatif deskriptif dengan melakukan survei dan wawancara pada mitra Go Food di Daerah Wirobrajan Yogyakarta, produsen merasa sangat terbantu dengan menjadi mitra Go food yang mana mengalami kenaikan dalam penjualan, dapat membantu memasarkan warung mereka dengan cara online. Serta dalam pendistribusian lebih cepat dan meberikan kemudahan kepada pelanggan sendiri untuk membeli produk dari produsen tanpa harus datang ke warung.
\end{abstract}

Kata kunci: perilaku produsen, kemitraan, Go Food

\section{PENDAHULUAN}

Perkembangan globalisasi yang di ikuti dengan perkembangan ilmu pengetahuan dan teknologis menjadi gambaran dalam kemajuan suatu bangsa, teknologi menajadi gambaran perkembangan suatu perekonomian dalam suatu negara dan menjadi kekuatan dalam persaingan pasar global. Hadirnya ekonomi digital mampu menjawab tantangan bagi sektor ekonomi mikro ataupun usaha yang baru star up untuk bisa bersaing terhadap sesama UMKM serta bersaing dalam pangsa pasar global.

Perkembangan ekonomi digital di Indonesia ikut menjadi trend di Indonesia, adanya perkembangan ekonomi digital muncul lah aplikasi berbasis online di Indonesia yang membawa perekonomian Indonesia serta membantu aktivitas masyarakat di Indonesia adanya aktivitas masyarakat yang menggunakan aplikasi online yang mempunyai banyak layanan fitur, salah satunya yang sangat terkenal di Indonesia yaitu pada aplikasi layanan Go jek.

Gojek merupakan perusahaan berjiwa sosial yang memimpin revolusi industri yang memberikan kemudahan bagi masyarakat. PT Gojek Indonesia didirikan oleh Nadiem Kariem adalah perusahaan di bidang jasa transportasi 
juga pengantar barang (kurir), dengan orientasi sosial yakni membantu para ojek agar dapat bekerja dengan lebih efisien.(caroline,2016). PT Gojek selain sebagai pengantar penumpang dia juga menawarkan berbagai layanan lain berupa Go Food, Go Mart, Go Box, Go Massage.

Go Food merupakan layanan baru yang diperkenalkan pada layanan Gojek tahun 2015, Go Food merupakan sebuah fitur layanan food delivery yang layaknya seperti delivery order pada sebuah restoran atau rumah makan yang ada sebelumnya. Hanya dengan menggunakan smartphone dan membuka fitur Go Food didalam aplikasi Gojek, konsumen bisa memesan makanan dari restoran atau rumah makan yang sudah menjadi mitra Gojek. Tujuan Go Jek mendirikan dari Go Food yaitu untuk membantu para UMKM meningkat penjualannnya, di samping itu UMKM merupakan penyumbang tersebesar PDB Indonesia yakni sekitar 57,94\% atau Rp. 4.3030,57 triliun. (Caroline,2016)

Kota Yogyakarta merupakan kota yang mempunyai banyak berbagaimacam kuliner serta rumah makan atau restoran jika dibandingkan dengan kabupaten atau kota terdekat dan Provinsi lainnya. Perkembangan industri kuliner yang semankin meningkat di Kota Yogyakarta yang di Tunjang sebagai Kota pelajar serta mengikuti perkembangan zaman yang semakin canggihnya teknologi. Salah satunya adalah layanan Go Food atau Food Delivery yang memudahkan masyarakat dalam memesan makanan ketika mereka sibuk bekerja atau ketika sedang kuliah. Bagi pegusaha khususnya pengusaha usaha mikro dengan adanya layanan Go Food ini menjadi solusi alternatif sendiri yang sangat membantu, pengusaha tidak perlu biaya tambahan ekstra untuk menggaji SDM untuk melakukan food delivery.

Fitur Go Food yang dikembangkan Go Jek jelas menguntungkan semua pihak, baik bagi konsumen, memudahkan dalam hal memesan makanan, sedangkan bagi Go Jek, bisa menambahkan pemasukan dengan bayaknya orderan yang masuk dari via Go Food, sedangkan bagi perusahaan, memberikan potensi kenaikan omzet penjualan dari layanan Go Food yang seperti halnya yang dirasakan oleh pelaku usaha yang bermitra dengan Go Food.
Menurut Suriadi kemitraan adalah kerja sama antara dua pihak dengan kewajiban yang setara dan saling menguntungkan, dalam peraturan pemerintah No 44 Tahun 1997 tentang kemitraan juga telah dijelaskan bahwa arti dari kemitraan adalah kerjasama usaha antara usaha kecil dengan usaha menengah atau usaha besar dengan memperhatikan prinsip saling memerlukan, saling memperkuat dan saling menguntungkan. (Ghassani,2015). Kemitraan pada PT Go jek kemitraan yang dimaksudkan memiliki hubungan atau jalinan kerja sama sebagai mitra. Dan perusahaan menggunakan perjanjian kerjasama kemitraan, dalam hal ini perusahaan sebagai mitra I dan mitra Go Food (pengusaha) sebagai mitra II, yang mana mitra I dan II mengadakan perjanjian kerjasama kemitraan dengan sistem hasil tertentu yang sudah disepakati dari awal, Agar tidak merugikan salah satu belah pihak.

Dalam islam terdapat ajaran pentingnya kemitraan di jelaskan Quran surah asy Syu'araa (26:183): (Rivai, 2013).

Bekerjasamalah kamu dalam hal kebajikan dan taqwa dan jangan sekali-kali bekerjasama dalam kejahatan dan keburukan

Dalam hal ini Islam mengajarkan kemitraan yang Islami harus memberi keuntungan kepada semua pihak.(Hakim,2009), seperti halnya dalam faktor-faktor produksi produsen berusaha untuk memproduksi barang atau jasa yang dibutuhkan masyarakat dan untuk memperoleh keuntungan maksimum dengan usaha tersebut.

Perilaku produsen merupakan proses dalam pengaplikasiannya yang terdapat nilainilai produksi Islami ke dalam setiap aktvitas produksinya. Karena dalam kegiatan produksi tidak lepas dari etika seorang produsen atau perusahaan harus menjunjung tinggi nilainilai baik yang berhubungan dengan Tuhan maupun manusia dan alam. Karena banyaknya dari perusahaan-perusahaan yang kurang mempedulikan etika produsen yang mana bisa menimbulkan kegagalan dalam produksi yang ada dalam perusahaan sehingga bisa merugikan perusahaan sendiri.

Seperti halnya sistem kemitraan Go Food memberikan dampak positif terhadap UMKM di Kota Yogyakarta khususnya daerah 
Wirobrajan, baik pemilik restoran mewah maupun rumah makan bagus yang enak dan berkualitas bagus di pinggir jalan, layanan Go Food sekitar 82 persen mitra UMKM mengalami peningkatan volume transaksi, selain itu 30 persen terjadi pengurangan biaya mitra UMKM setelah bergabung dengan Go Jek melalui layanan Go Food. Peningkatan jumlah pelanggan dan omzet penjualan.

Adanya peran perilaku produsen dalam perusahaan sehingga sistem kemitraan bisa berjalan lancar dan memberikan keutungan. Dari pendahuluan di atas penulis ingin mengambil 3 sampel responden secara acak , dan menujukan bahwa layanan Go Food memberikan dampak positif terhadap kenaikan omzet penjualan yang memberikan banyak keuntungan terhadap mitra Go Food signifikan atau tidak. Karena dilihat dari meningkatnya mitra Go Food di Kota Yogyakarta yang menggunakan layanan Go Food, dilihat dari sisi kerjasama dan keuntungan mitra Go Food. Maka peneliti menarik kesimpulan judul penelitian ini adalah "Perilaku Produsen Pada Model Kemitraan Go Food Dalam Prespektif Ekonomi Islam".

\section{TEORI KEMITRAAN DALAM PRESPEKTIF KONVENSIONAL DAN DALAM EKONOMI ISLAM Pengertian Teori Kemitraan}

Kemitraan, dalam kontek ini secara normal merupakan sebuah hungan informal dimana para mitra secara efektif mengakui dan mengejar dalam kepentingan bersama. Muhammad Jafar, kemitraan adalah suatu strategi bisnis yang dilakukan oleh dua pihak atau lebih dalam jangka waktu waktu tertentu untuk meraih keuntungan bersama dengan prinsip saling membutuhkan dan saling membesarkan. (Jafar,2000)

Sedangkan dalam undang-undang republik Indonesia no 9 tahun 1995 kemitraan adalah kerjasama usaha antara usaha kecil dan usaha menengah atau usaha besar disertai pembinaaan dan pengembangan oleh usaha menengah atau usaha besar memperhatikan prinsip saling memerlukan, saling memperkuat dan saling menguntungkan. (Saly, 2001).

Jadi menurut para ahli kemitraan adalah hubungan antara dua pihak atau lebih yang bertujuan untuk mencari keuntungan dimana satu pihak berada dalam kondisi yang lebih rendah dari yang lainnya namun membentuk suatu hubungan yang mendukung keduanya berdasarkan kata sepakat untuk mencapai suatu tujuan. Dan kemitraan usaha untuk pembangunan kesejahteraan rakyat. (Saly,2001)

\section{Manfaat Kemitraan}

1. Efisiensi dan efektifitas yaitu, memproduksi barang dan jumlah yang diharapkan dengan mengurangi faktor input dan meningkatkan produksi (output) dengan menggunakan sumberdaya dalam jumlah dalam kualitas yang besar.

2. Jaminan mutu, jumlah dan keberlanjutan mulai dari penyedia input, proses hingga output yang dihasilkan.

3. Mengurangi resiko dan mengingkatkan keutungan

4. Memberi manfaat sosial

5. Meningkatkan pendapatan dan kesejahteraan

6. Mendukung keberlangsungan program

\section{Kemitraan dalam Ekonomi Islam (Musyarakah)}

Kemitraan dalam Ekonomi Islam lebih dikenal dengan Musyarakah yang berasal dari kata Syirkah, yaitu berarti al-ikhtilath yang artinya campur atau percampuran. (Suhendi,2007), Konsep dalam ekonomi Islam, Kemitraan atau Syirkah adalah bentuk umum dari usaha bagi hasil dimana dua orang atau lebih menyumbangkan dan manajemen pembiyaan usaha, dengan proporsi bisa sama atau tidak. Keuntungan dibagi berdasarkan kesepakatan para mitra, dan kerugian akan dibagikan menurut proporsi modal. Dalam transaksi ini dilandasi adanya keinginan para pihak yang bekerjasama untuk meningkatkan nilai aset yang mereka nilai secara bersamasama dengan mendukung seluruh sumber daya yang ada. (Ascarya,2007)

Dalam kemitraan, adanya landasan sumber dasar hukum syirkah yang dijelaskan dalam terjemahan surat Al-Maidah ayat 2 ;

Hai orang-orang yang beriman, janganlah kamu melanggar syi'ar-syi'ar Allah, dan jangan melanggar kehormatan bulan-bulan haram, jangan (mengganggu) binatang- 
binatang hadya, dan binatang-binatang qalaa-id, dan jangan (pula) mengganggu orang-orang yang mengunjungi Baitullah sedang mereka mencari kurnia dan keredhaan dari Tuhannya dan apabila kamu Telah menyelesaikan ibadah haji, Maka bolehlah berburu. dan janganlah sekali-kali kebencian(mu) kepada sesuatu kaum Karena mereka menghalang-halangi kamu dari Masjidilharam, mendorongmu berbuat aniaya (kepada mereka). dan tolongmenolonglah kamu dalam (mengerjakan) kebajikan dan takwa, dan jangan tolong-menolong dalam berbuat dosa dan pelanggaran. dan bertakwalah kamu kepada Allah, Sesungguhnya Allah amat berat siksa-Nya. (Qs. Almaidah:2).

Maksud penjelasan terjemahan ayat Allah telah berfirman agar manusia saling tolong menilong dan bersama-sama untuk tujuan yang baik, dengan kata lain kemitraan adalah bentuk kerjasama usaha atas dasar tolong menolong antara sesama manusia dengan tujuan mendapatkan profit, dalam hal ini profit yang dimaksud akad yang terletak pada prinsipprinsip yang berdasarkan ketentuan-ketentuan ajaran Islam. Seperti halnya kemitraan yang terjalin antar PT Gojek dengan Mitra Go food yang mana dalam kegiatan bisnis ini harus melakukan sesuatu dengan cara yang baik pada saat melakukan bisnisnya.

Hal ini di perkuat dengan adanya unsurunsur yang harus ada dalam akad atau rukun berdasarkan akad syirkah dalam kegiatan ekonomi Islam (zulkifli,2004) :

1. Para pihak yang berserikat

2. Porsi kerjasama

3. Proyek atau kerjasama

4. Ijab qobul

5. Nisbah bagi hasil

\section{Indikator Kemitraan}

Untuk dapa mengetahui keberhasilan proses kemitraan diperlukan adanya yang dapat di ukur menurut (Ditjen P2L\&PM dalam Kuswidanti 2008:22) sebagai berikut:

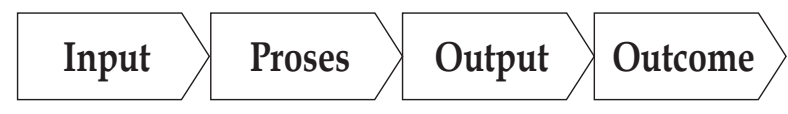

Gambar I. Indikator kemitraan

\section{Indikator input}

Tolak ukur keberhasilan input dapat diukur dari tiga indikator yaitu :

a. Terbentuknya tim wadah atau sekretariat yang ditandai dengan adaya kesepakatan bersama kemitraan.

b. Adanya sumber dana/biaya yang memang diperuntukan bagi pengembangan kemitraan.

c. Adanya dokumen perencanaan yang telah disepkati oleh institusi terkait.

\section{Indikator proses}

Tolak ukur keberhasilan proses dapat diukur dari indikator frekuensi atau pertemuan sesuai kebutuhan. Hasil evaluasi terhadap proses nilai yang berhasil.

\section{Indiktor output}

Tolak ukur keberhasilan output dapat diukur dari indikator sebagai berikut jumlah kegiatan yang terkait dengan instusi tersebut dengan kesepakatan peran masing-masing institusi. Hasil evaluasi terhadap output dinilai berhasil apabila tolak ukur tersebut terbukti ada.

\section{Indikator outcome}

Tolak ukur outcome adalah menurunnya angka permasalahan yang terjadi.

\section{Indikator Musyarakah (kemitraan)}

Indikator musyarakah merupakan objek yang dilakukan dalam Musyarakah yaitu (Nurhayati,2012):

\section{Modal}

a. Modal harus diberikan tunai

b. Modal berupa uang tunai, emas, perak dan sebagainya.

c. Apabila modal yang diserahkan oleh setiap mitra harus dicampur tidak boleh memisahkan modal masing-masing pihak

d. Dalam kondisi normal, setiap mitra memiliki aset.

e. Modal yang ditanamkan tidak boleh di investasikan yang dilarang syariah.

\section{Kerja}

a. Partisipasi dalam bekerja merupakan dasar pelaksanaan musyarakah 
b. Tidk dibenarkan bila salah seorang tidak ikut dalam pekerjaan mengenai mitra

c. Porsi kerja antara mitra tidak harus sama, mitra yang porsinya banyak boleh memintak bagian keuntungan yang lebih besar.

d. Para mitra harus menjalankan usahanya sesuai dengan syariah.

\section{Ijab qabul}

Ijab qabul adalah pernyataan dan saling rela diantara pihak-pihak perilaku akad yang dilakukan secara verbal, tertulis, melalui korespodensi atau komunikasi moderen.

\section{Nisbah}

a. Pembagian keuntungan dan harus disepakati oleh para mitra diawal akad sehingga resiko perselisihan diantara para mitra.

b. Perubahan nisbah harys berdasarkan kesepakatan kedua belah pihak.

c. Keuntungan harus ditentukan dasar penghitungan keuntungnnya.

\section{Definisi Perilaku Produsen}

Kegiatan produsen pada dasarnya mengetegahkan sikap seorang pengusaha dalam memproduksi barang dan jasa. Sementara itu produksi sendiri adalah menciptakan manfaatnya. Produsen adalah suatu lembaga perusahaan perorangan yang berperan dalam menaikan nilai guna suatu barang atau jasa sehingga menghasilkan barang konsumsi untuk memenuhi kebutuhan. Perilaku produsen dapat diartikan suatu yang mewakili apa yang diyakini oleh produsen dalam mengambil keputusan untuk menjual dan mencari keuntungan.

Adapun faktor-faktor yang mempengaruhi perilaku produsen dilihat dari :

1. Kekuatan sosial budaya terdiri faktor budaya, tingkat nasional.

2. Kekuatan psikologis terdiri dari pengalaman belajar, kepribadian sikap dan keyakinan.

3. Tujuan dan fungsi modal perilaku produsen sangat bermanfaat dan mempermudah dalam mempelajari apa yang telah kethui mengenali perilaku produsen.

Sedangkan dalam ekonomi Islam, Penjelasan perilaku produsen yaitu (Rianto,2011):
1. Siddiqi (1992) mendefinisikan kegiatan produksi sebagai penyediaan barang dan jasa dengan memperhatikan nilai keadilan dan kemanfaatan (maslahah) bagi masyarakat. Dalam pandangannya sepanjang produsen telah bertindak adil dan membawa kebajikan bagi masyarakat maka ia telah bertindak Islami.

2. DrMuhammad Rawwas Qalahji memberikan kata produksi dalam bahasa arab dengan kata al-intaj yang secara harfiah dimaknai dengan ijadu sil'atin (mewujudkan atau mengadakan sesuatu) atau khidmatu mu'ayyanatin bi istikhdami muzayyajin min anashir alintaj dhamina itharu zamaninmuhaddadin (pelayanan jasa yang jelas dengan memenuhi bantuan adanya penggabungan unsur-unsur produksi yang terbingkai dalam waktu yang terbatas).

3. Kahf mendefinisikan kegiatan produksi dalam prespektif islam sebagai usaha manusia untuk memperbaiki tidak hanya kondisi fisik materialnya, tetapi moralitas juga, sebagai sarana untuk mencapai tujuan tertentu sebagaimana digariskan dalam agama yaitu kebahagian dunia dan akhirat.

Dalam beberapa pandangan diatas bahwa sepanjang kegiatan produsen telah bertindak adil dan membawa kebajikan bagi masyarakat maka dapat dikatakan telah bertindak islami. Serta ketika suatu proses untuk menghasilkan barang dan jasa, berdasarkan ketersediannya dari faktor produksi, maka untuk memenuhi kebutuhan barang dan jasa dapat memperhatikan nilai keadilan dan mashlahah.

\section{METODE PENELITIAN}

Metode penelitian pada dasarnya atau teknis yang diharapkan mampu menemukan, merumuskan,dan menganalisa atau ,memecahkan masalah-masalah dan data yang diperoleh secara akurat,nyata.

\section{Jenis penelitian}

Penelitian ini adalag penelitian yang menggunakan metode penelitian lapangan (field research). Penelitian ini menggunakan penelitian kualitatif deskriptif. Metode penelitian kualitatif yaitu metode yang datanya 
dinyatakan dalam bentuk kata-kata atau kalimat yang mendukung. dalam penelitian ini juga menggunakan data primer dan sekunder dengan mengkaji data-data primer yang sudah didapatkan dari penelitian lapangan yang disajikan sesuai dengan data yang diperoleh. (Sugiyono,2015)

\section{Lokasi penelitian}

Lokasi penelitian in cakupan yang menjadi basis penelitian ini. Dalam penelitian ini lokasi di kota Yogyakarta di tentukan secara sengaja (purposive) , karena dilihat dari banyaknya warung makan di kota Yogyakarta yang bermitra dengan Go Food yang sudah berjalan selama dua bulan sampai satu tahun dilihat dari keramaian warung tersebut sebelum dan setelah bergabung.

\section{Tehnik pengumpulan data}

Tehnik pengumpulan data pada penelitian ini menggunakan, yaitu wawancara, dokumentasi, keabsahan data. Adapun penelitian ini dilakukan oleh warung makan yang bermitra dengan go food sebanyak 3 responden.

\section{Tehnik analisi data}

Tehnik analisis data yang digunakan dalam penelitian ini terdiri dari:

\section{Reduksi data}

Mereduksi data berarti merangkum kumpulan data. Memilih hal-hal yang pokok, fokus pada hal-hal yang penting, dan mencari tema dan polanya. Data yang telah direduksi akan memberikan gambaran yang lebih jelas, sehingga mempermudah peneliti untuk mengumpulkan data selanjutnya.

\section{Penyajian data}

Penyajian data merupakan sebagai informasi tersusun yang memberikan kemungkinan adanya penarikan kesimpulan dan pengambilan tindakan.

\section{Kesimpulan atau verifikasi.}

Kesimpulan yang dibuat masih bersifat sementara dan bisa saja akan berubah sampai ditemukan bukti-bukti kuat yang mendukung pada tahap pengumpulan data berikutnya. Akan tetapi, apabila kesimpulan yang dibuat pada tahap awal didukung oleh bukti-bukti yang valid dan konsisten, maka kesimpulan yang dikemukakan adalah kesimpulan yang kredibel.

\section{HASIL DAN PEMBAHASAN \\ Perilaku Produsen pada Model Kemitraan Go Food dalam Prespektif Ekonomi Islam}

Teori perilaku produsen dalam prespektif Islam merupakan ilmu yang mempelajari perilaku ekonomi manusia dimana perilakunya diatur berdasarkan agama Islam. Produsen adalah suatu lembaga perusahaan perorangan yang berperan dalam menaikan nilai guna suatu barang atau jasa sehingga menghasilkan barang konsumsi untuk memenuhi kebutuhan. Karena seorang produse harus proaktif, kreatif dan inovatif dalam menemukan berbagai barang dan jasa yang dibutuhkan oleh manusia, dan dalam menghasilkan barang dan jasa yang bermanfaat bagi kehidupna masa mendatang. Maka seorang produsen dapat bekerja sama dengan pihak tertentu,sebagai suatu pengembangan usaha kecil, kemitraan adalah hubungan antara dua pihak atau lebih yang bertujuan untuk mencari keuntungan dimana satu pihak berada dalam kondisi yang lebih rendah dari yang lainnya namun membentuk suatu hubungan yang mendukung keduanya berdasarkan kata sepakat untuk mencapai suatu tujuan. Dan kemitraan usaha untuk pembangunan kesejahteraan rakyat.

Pada penelitian ini menganalisis indikator-indikator kemitraan Go food dalam prespektif ekonomi Islam sebagai berikut :

Modal, penerapan modal pada model kemitraan Go food tidak ada karena penanaman modal semuanya dari produsen, kegiatan kemitraan ini dilakukan untuk mempermudah para konsumen dalam pemesanan makanan yang dilakukan dengan aplikasi berbasis digital sehingga memberi kemudahan para konsumen dalam pembelian,bisa diperjelas lagi bahwa seluruh modal produsen baik untuk proses produksi barang mentah menjadi barang jadi , maupun pemilihan lokasi semua ditentukan pada produsen sendiri. Yang kita ketahui dalam teori indiktor kemitraan yaitu adanya penyerahan modal, tetapi berbeda halnya pada kemitraan pada Go food. 
Kerja, bentuk indikator ini adalah kerja yang memiliki dua pengertian yaitu pihak pertama Go food yang sama-sama bekerja sebagai penyedia jasa ketika adanya pihak konsumen yang membeli makanan, sedangkan pihak kedua yaitu produsen sekaligus yang memproduksi barang dan jasa yang dihasilkan, pada sistem kemitraan ini pihak Go food juga sebagai penyedia jasa pemasaran. Pada penerapan kemitraan Go food dalam prespektif ekonomi Islam dari segi praktek maupun teori sangat sesuai yang mana dilihat dalam teori indikator kemitraan bahwa tidak dibenarkan bila salah seorang tidak ikut serta dalam mengenai pekerjaan mitra, selain itu para mitra harus menjalankan usahanya sesuai degan syariah. Karena bisa dilihat mereka saling bekerja serta tidak merugikan sesama belah pihak. Kerja merupakan salah satu cara yang halalan thayyibah untuk memperoleh harta yaitu dengan seorang bekerja. (P3EI,2008)

Ijab qobul, dalam ekonomi Islam Ijab qabul juga dikenal dengan akad atau perjanjian karena dalam menjalin kemitraan perlunya akad antara dua belah pihak untuk menghindari kesalahpahaman, seperti halnya yang disampaikan oleh Ibu Aisyah penjual batagor dan siomay yang sudah bergabung selama satu dua tahun yang menjelaskan bahwa sebelum bergabung dengan mitra Go food maka seorang produsen harus mengisi formulir yang disediakan oleh pihak Go food Gojek yang pertama melakukan pendaftaran melalui web, mengisi formulir registrasi online yang mencakup (KTP,nomor NPWP pemilik warung makan, menempilkan nama warung, data pembayaran, nama outlet, nomer outlet untuk log in ke aplikasi ), kedua dan mengisi data pemilik warung ataupun restoran. (Aisyah, 2019)Sama seperti halnya yang disampaikan oleh Ibu Mudia penjual salad nyonyah2 yang menjelaskan adanya akad sebelum bergabung dengan mitra Go food.(Mudia,2019), Akad yang dilakukan pada sistem kemitraan ini dilakukan secara jelas dan terperinci baik secara tulisan maupun menggunakan cara-cara komunikasi hal ini juga sangat sesuai dengan teori dari indikator kemitraan pada proses ijab qabul.

Berdasarkan hasil survei yang dilakukan peniliti melalui 3 responden yang bermitra dengan go food yaitu mereka merasakan kemudahan para pengusaha untuk bertemu dengan produsen, dan memudahkan dalam mendistribusikan barang produksinya, serta meningkatkan citra perusahaan tanpa perlu produsen mengeluarkan biaya jasa pemasaran maupun promosi. Hal ini dijelaskan oleh bapak Ali penjual Adm Pisang membenarkan bahwa dengan bermitra dengan go food merasa di mudahkan dalam hal promosi dan serta dalam pendistribusian barang. Serat merasa terbantu dalam biaya dari segi kenaikan pelanggan.

Nisbah, dalam setiap sistem kemitraan adanya sistem pembagian yang diterapkan dalam kemitraan tersebut, seperti halnya sistem pembagian hasil yang dilakukan oleh mitra go food yang dilakukan berdasarkan kesepakatan pada proses akad yang sudah dijelaskan di atas. Sistem pembagian keuntungan yang dilaksanakan di Go food dalam pembelian makanan sebesar 20 persen, hal ini dijelaskan oleh pemilik warung pisang Adm bapak Ali yang memberikan penjelasan bahwa dalam sistem pembagian keuntungan penjualan makanan sebesar 20 persen, selain itu juga pihak produsen harus menaikan harga dalam aplikasi yang terdapat di Go food Gojek karena adanya perbedaan harga dari harga normal dengan harga melalui vi aplikasi tetapi hal ini tidak merugikan pihak produsen karena dengan bermitra dengan Go food sistem penjualannya mengalami kenaikan. Hal ini di perkuat dalam teori bahwasanya dalam pembagian keuntungan dalam kemitraan sama-sama disepakati dari awal akd sehingga resiko perselisihan diantara para mitra dapat dihilangkan.

\section{KESIMPULAN}

Perilaku produsen dalam prespektif Islam merupakan ilmu yang mempelajari perilaku ekonomi manusia dimana perilakunya diatur berdasarkan agama Islam. perilaku produsen dalam ekonomi Islam sangat menjunjung tinggi kejujuran. seorang produse harus proaktif, kreatif dan inovatif dalam menemukan berbagai barang dan jasa yang dibutuhkan oleh manusia, dan mampu menciptakan sesuatu tanpa meniru orang lain.

Kemitraan adalah hubungan antara dua pihak atau lebih yang bertujuan untuk mencari keuntungan dimana satu pihak berada 
dalam kondisi yang lebih rendah dari yang lainnya namun membentuk suatu hubungan yang mendukung keduanya berdasarkan kata sepakat untuk mencapai suatu tujuan. Model kemitraan go food di daerah Wirobrajan Yogyakarta para produsen merasa sangat terbantu dengan menjadi mitra Go food yang mana mengalami kenaikan dalam penjualan, dapat membantu memasarkan warung mereka dengan cara online. Serta dalam pendistribusian lebih cepat dan meberikan kemudahan kepada pelanggan sendiri untuk membeli produk dari produsen tanpa harus datang ke warung.

\section{SARAN}

Untuk mitra Go food agar lebih meningkatkan kualitas produknya. Menjaga sistem pola kemitraan antara pihak produsen dan gojek. Untuk Model kemitraan Go Food Gojek untuk meningkatkan kualitas sistem aplikasi agar tidak terjadi traouble,serta menjaga keaman barang hingga sampai ke tangan konsumen.

Untuk penelitian selanjutnya diharapkan peneliti bisa memperkuat teori model kemitraan yang ada,serta menambah variabel selain Go Food, atau membandingkan antara model kemitraan Go Food dengan Grab Food.

\section{DAFTAR PUSTAKA}

Ascarya, (2007). Akad dan Produk Bank Syariah. Jakarta: PT. Raja Grafindo Persada

Hendi Suhendi, (2007).Fiqih Muamalah. Jakarta: PT. Raja Grafindo Persada.
P3EI,(2008). Ekonomi Islam. Jakarta: PT Raja Grafindo Persada.

Ryandono, Muhammad Nafik Hadi(2008). Ekonomi ZISWAQ (Zakat, Infaq, Shadaqah dan Waqaf). Surabaya: IFDI dan Cenforis.

Sri nurhayati, (2012).Akuntansi Syariah Di Indonesia. Jakarta: salemba empat.

Sugiyono,(2015).Metode Penelitian Pendidikan (pendekatan kuantitatif,kualitatif, danRED). Bandung:Alfabeta.

Sunarto zulkifli, (2004).Panduan Praktis Transaksi Perbankan Syari'ah, jakarta: zikrul hakim.

Caroline,Angela (2016). Evaluasi Tawaran Kerjasama Kemitraan Dengan Go-Mart Dari Sudut Pandang Konsumen Dan Usaha Retail Di Kota Bandung. Jurnal Ekonomi, Manajemen dan Perbankan.Vol 2. pp. 2302-4119

Rosni,(2012).Analisis Tingkat Kesejahteraan Masyarakat Nelayan Di Desa Dahari Selebar Kecamatan Talawi Kabupaten Batubara. Jurnal Unimed pp: 2549-7057

MNur Rianto Al-Arif,(2011).Dasar-dasar ekonomi Islam. Solo : Perpustakaan nasional RI.

Jeane,Neltje,Saly,(2001).Usaha Kecil, Penanaman Modal Asing Dalam Peresfektif Pandangan Internasional, Jakarta: badan pembinaan hukum nasional.

Wawancara responden 1 , Aisyah.(2019), pemilik siomay dan batagor

Wawancara responden II, Mudia.(2019),pemilik salad nyonyah 2

Wawancara responden III, Ali.(2019), pisang Adm 